Original Paper http://ajol.info/index.php/ijbcs http://indexmedicus.afro.who.int

\title{
Pollination efficiency of Apis mellifera (Hymenoptera: Apidae) on Solanum nigrum (Solanaceae) at Meskine (Maroua, Cameroon)
}

\author{
Jean MAMOUDOU ${ }^{1}$, Sidonie Fameni TOPÉ ${ }^{1 *}$, Emmanuel BASGA ${ }^{2}$ and \\ Fernand-Nestor Tchuenguem FOHOUO $^{3}$
}

\author{
${ }^{1}$ Department of Biological Sciences, Faculty of Science, University of Maroua, \\ P.O. Box 814, Maroua, Cameroon. \\ ${ }^{2}$ Department of Earth and Life Sciences, Higher Teachers' Training College, University of Maroua, \\ P. O. Box 46, Maroua, Cameroon. \\ ${ }^{3}$ Department of Biological Sciences, Faculty of Science, University of Ngaoundéré, \\ P. O. Box 454, Ngaoundéré, Cameroon. \\ "Corresponding author; E-mail: sidofameni@gmail.com; Tel. (+237)697438668/(+237)678396121
}

\begin{tabular}{ccc}
\hline Received: 13-04-2021 & Accepted: 19-06-2021 & Published: 30-06-02021 \\
\hline
\end{tabular}

\begin{abstract}
Most plant species require pollen transfer to produce fruits and set seeds. Although some insects visit flowers for nectar or pollen, not all flowering insects bring about pollination. To evaluate the impact of Apis mellifera Linnaeus on fruit and seed yields of Solanum nigrum Linnaeus, foraging and pollinating activities of worker bees were studied at Meskine in January 2019 and February 2020. The experiments were carried out on 540 flowers divided in four treatments: two treatments differentiated according to the presence or absence of protection of flowers regarding A. mellifera and other insect visits; the third with flowers protected and uncovered when they were opened, to allow A. mellifera visits and the fourth with flowers protected then uncorvered and reprotected without the visit of insects or any other organism. The foraging behaviour of $A$. mellifera on flowers, its efficiency pollination, the fruiting rate, the number of seeds per fruit and the percentage of normal seeds were evaluated. Results indicate that among 27 insect species recorded on flowers, A. mellifera ranked first accounting for for $34.16 \%$ of 2652 visits. This worker bee intensely harvested nectar and pollen. The mean foraging speed was 10.39 flowers / min. The mean abundance per 1000 flowers was 519.46. For the two years, throughout its pollination efficiency, A. mellifera increased the fruiting rate by $16.29 \%$, as well as the percentage of normal seeds by $15.57 \%$. Hence, the installation of honeybee colonies close to S. nigrum fields is recommended to improve fruit yields, seed quality, pollen as a hive product and honey production.
\end{abstract}

(C) 2021 International Formulae Group. All rights reserved.

Keywords: Honeybee, Far North, apicultural value, flowers, yields.

\section{INTRODUCTION}

Pollinators play an important role in the sustainability of ecosystems and agriculture (Klein et al., 2007). Nearly $80 \%$ of the commercial crops are pollinated by insects
(Free, 1993). Honeybees are well adapted to pollination because their sense of smell, eyes, mouthparts, and numerous branched body hairs are ideally suited for searching food sources, sipping nectar, collecting and distributing 
pollen (Abrol, 2012). Pollination is an ecosystem service in that wild pollinators, in particular wild bees, contribute significantly to the pollination of a large array of crops (Winfree et al., 2008; Mohamadou et al., 2018). In the natural environment and in agro ecosystems, flowering insects in general and Apoidea in particular have great ecological and economical importance because they have a positive influence on food production (Dounia and Tchuenguem, 2013; Basga et al., 2018). Besides, the activity and diversity of flowering insects of a plant vary with place and period (Abrol, 2012; Tchuenguem et al., 2014).

Solanum nigrum occupies an important place in the world economy and contributes effectively to food security (Asseng et al., 2017). It is grown widely in temperate and tropical region (Olmstead et al., 2008). In Africa, mainly in Ivory Coast and Cameroon, it is grown in small farms and vegetable gardens for market supply. Solanum nigrum is an excellent source of iron, calcium, proteins, vitamins $\mathrm{A}$ and $\mathrm{C}$, iodine and zinc (Schippers, 2000). It generally provides few calories to the human body (Schippers, 2000) and contains soluble fibers (Agbo et al., 2009) which facilitates digestion. The plant extracts are used as an analgesic, antispasmodic, antiinflammatory and vasodilator (Duke and Ayensu, 1985).

Solanum nigrum is an annual plant (Edmonds and Chweya, 1997). Its flowers have whitish petals that surround bright yellow anthers (Edmonds and Chweya, 1997). The flower is hermaphrodite and produce both nectar and pollen, which attract insects (Schippers, 1998).

The flowers remain on the plants for ten days acting as a visual 'flag' to the pollinators (Edmonds and Chweya, 1997). In Cameroon, S. nigrum is cultivated as vegetable (Schippers, 1998) and there are no reliable statistics on production and trade (Aboubakar et al., 2020). Nevertheless, there are exports of $S$. nigrum leaves from Cameroon to Nigeria and Gabon.

In Cameroon, Aboubakar et al. (2020) have reported lack of seeds due to soil degradation. In Nigeria, Okafor (1997) also revealed lack of seeds and seedling mortality which is a direct effect of poor seed quality and vigour. In this country, $S$. nigrum flowers were reported to produce fewer seeds per fruit in the absence of efficient pollinators (Oyelana and Ogunwenmo, 2012). Therefore, to widespread cultivation of $S$. nigrum as leafy vegetables, it is important to investigate on the possibilities of increasing seed production of this plant. Informations obtained on the interaction between $S$. nigrum and its anthophilous insects will allow farmers to develop management strategies that can contribute to increase the quantity and quality of $S$. nigrum yields. During preliminary observations on flowerinsect relationships in Maroua before 2017 (unpublished data), A. mellifera has been seen intensively visiting flowers of $S$. nigrum. Investigations on foraging and pollinating activities of A. mellifera on S. nigrum flowers in Cameroon could provide essential data for their optimal management. Indeed, Solanum nigrum is one of the many plants species for which informations on pollination by insects in Cameroon remain unknown.

\section{MATERIALS AND METHODS}

\section{Study site, experimental plot and biological material}

The experiments were carried out from $5^{\text {th }}$ January to $8^{\text {th }}$ February 2019 and from $4^{\text {th }}$ February to $8^{\text {th }}$ March 2020 at Meskine (latitude: $10^{\circ} 32^{\prime} 26^{\prime \prime} \mathrm{N}$; longitude: $14^{\circ} 14^{\prime} 53^{\prime \prime}$ E; altitude: $410 \mathrm{~m}$ above sea level), a Western suburb of Maroua in the Far North Region of Cameroon. This Region belongs to the ecological zone with three phytogeographical areas (Sudano-Sahelian, Sahelian and Sudanian altitude) periodically flooded, with unimodal rainfall (Letouzey, 1985). The climate is characterized by two seasons: a dry season (November to May) and a rainy season (June to October); August is the wettest month of the year (Letouzey, 1985). Annual rainfall varies from 400 to $1100 \mathrm{~mm}$; the annual average temperature varies between $29^{\circ} \mathrm{C}$ and $38^{\circ} \mathrm{C}$ and a daily temperature range between 6 ${ }^{\circ} \mathrm{C}$ and $7{ }^{\circ} \mathrm{C}$ (Letouzey, 1985). The experiment plot was a field of $437 \mathrm{~m}^{2}$. The animal material included A. mellifera and other insect species naturally occuring in the environment of the 
study site. The vegetation was represented by wild and cultivated species. The plant material was represented by $S$. nigrum whose seeds were provided by the Institute of Agricultural Research for Development of Garoua.

\section{Sowing and weeding}

From October $12^{\text {th }}$ to $19^{\text {th }} 2019$ and from October $22^{\text {nd }}$ to $30^{\text {th }} 2020$, the experimental plot was divided into 8 subplots of $8 * 4.5 \mathrm{~m}^{2}$ each. Three seeds were sown per hole on six lines per subplot. There were 16 holes per line. Holes were separated $50 \mathrm{~cm}$ from each other, while lines were $75 \mathrm{~cm}$ apart (Djakbé et al., 2017).

\section{Determination of the mode of reproduction of Solanum nigrum}

On January $4^{\text {th }} 2019,240$ flowers of $S$. nigrum at bud stage were labeled and divided in two treatments: 120 unlimited flowers (treatment 1) access by all visitors and 120 flowers bagged using gauze bags net to avoid insect visits (treatment 2) (Tchuenguem et al., 2001). Similarly, on February $3^{\text {rd }} 2020,240$ flowers at the budding stage were labeled of which 120 flowers were left unprotected (treatment 5), while 120 were bagged (treatment 6). For each cropping year, after harvest, the number of fruits formed in each treatment was assessed.

For each treatment, the fruiting index $\left(P_{i}\right)$ was then calculated as described by Tchuenguem et al. (2001): $\boldsymbol{P i}=\boldsymbol{F} \boldsymbol{b} / \boldsymbol{F a}$, where $F_{a}$ the number of viable flowers initially set and $F_{b}$ the number of formed fruits. For each year, the allogamy rate (Alr) from which derives the autogamy rate (Atr) was expressed as the difference in fruiting indexes between treatment $X$ (unprotected flowers) and treatment $Y$ (bagged flowers) (Demarly, 1977); Atr $=\{[(P i X-P i Y) / P i X] \times \mathbf{1 0 0}\}$, where $P i X$ and $P i Y$ are the fruiting indexes in treatments $X$ and $Y$ respectively; $\boldsymbol{A l r} \mathbf{=} \mathbf{1 0 0}-\boldsymbol{A t r}$.

\section{Estimation of the frequency of Apis mellifera visits on Solanum nigrum flowers}

Observations were conducted on 120 individual opened pollinated flowers of treatments 1 and 5, each day, from $18^{\text {th }}$ January to $26^{\text {th }}$ January 2019 and from $12^{\text {th }}$ to $30^{\text {th }}$ February 2020, according to six daily time frames: 6 - 7 a.m., 8 - 9 a.m., 10 - 11 a.m., 12 13 p.m., 14 - 15 p.m. and 16 - 17 p.m. In a slow walk along all labelled flowers of treatments 1 and 5, the identity of all insects that visited $S$. nigrum flowers was recorded. Specimens of all insect taxa were caught using insect net on unlabelled flowers and conserved in $70 \%$ ethanol, excluding butterflies that were preserved dry (Borror and White, 1991), for further taxonomic identification. All insects encountered on flowers were registered and the cumulated results expressed as the number of visits to determine the relative frequency of Apis mellifera in the anthophilous entomofauna of $S$. nigrum (Tchuenguem et al., 2009a). Data obtained were use to determine the frequency of visits $\left(F_{i}\right)$ of each insect species on $S$. nigrum flowers. For each study period, $F_{i}=[(V i / V t) \times 100]$ (Tchuenguem et al., 2001), where $V i$ is the number of visits of insect $i$ on treatment with unprotected flowers and $V t$, the total number of insect visits of all the recorded insect species on these flowers.

\section{Study of the foraging activity of Apis mellifera on Solanum nigrum flowers Floral products harvested}

In addition to the determination of the flower visiting insect frequencies, direct observation of the foraging activity of Apis mellifera on flowers was made in the experimental field. Workers were categorized based on their specific foraging behaviour. Nectar foragers were expected to be seen extending their proboscis between the base of the corolla and stamens, while pollen gatherers were supposed to scratch the anthers unsing their mandibles and legs (Jean-Prost, 1987). During the same time that the duration of $A$. mellifera visits on flowers was registered, the type of floral product harvested by the honeybee was noted (Tchuenguem, 2005). In the morning of each sampling day, the number of opened flowers was counted. Data obtained were used to determine the relationship between the number of visits of A. mellifera and the number of oppened flowers (Tchuenguem, 2005). 


\section{Duration of visits and foraging speed}

During the same days as for the registration of the frequency of visits, the duration of individual flower visit was recorded (using stopwatch) according to sixtime frames: 7 - 8 a.m., 9 - 10 a.m., 11 - 12 p.m., 1- 2 p.m., 3 - 4 p.m. and 5 - 6 p.m. Moreover, the number of visits during which the bee came into contact with the stigma (Jacob-Renacle, 1989) was registered.

Regarding the foraging speed $\left(F_{s}\right)$ which is the number of flowers visited by an individual bee per minute (Jacob-Renacle, 1989), data were registered during the same dates and according to the same time frames as for the duration of visits. The stopwatch, previously set to zero was switched on as soon as an individual landed on a flower and the number of visited flowers was concomitantly counted (Tchuenguem, 2005). The stopwatch was stopped as soon as the visitor was lost to sight or when it left $S$. nigrum flower for another plant species. The foraging speed $\left(F_{s}\right)$ was calculated using the following formula: $F_{s}$ $=\left(N f / d_{v}\right) * 60$, where $d_{v}$ is the duration (in sec) given by stopwatch and $N f$ the number of flowers visited during $d_{v}$ (Tchuenguem, 2005). During the observation, when a forager returned to previously visited flower, counting was performed as on two different flowers (Tchuenguem, 2005).

\section{Abundances per flower and per 1000 flowers}

The abundances of foragers (highest numbers of individuals foraging simultaneously) (Tchuenguem et al., 2004) per flower and per 1000 flowers $\left(A_{1000}\right)$ were recorded on the same dates and daily time frames as that for the registration of the duration of visits. Abundance per flower was recorded as a result of direct counting (Tchuenguem et al., 2004). For determining the abundance per 1000 flowers, foragers were counted on a known number of opening flowers and $A_{1000}$ was calculed using the following formula: $\boldsymbol{A}_{1000}=[(\boldsymbol{A x} / \boldsymbol{F x}) \times \mathbf{1 0 0 0}]$, where $F x$ and $A x$ are respectively the number of flowers and the number of foragers effectively counted on these flowers at time $x$ (Tchuenguem et al., 2004).

\section{Foraging ecology}

The disruption of the activity of foragers by competitors or predators and the attractiveness exerted by other plant species on A. mellifera was assessed by direct observations (Tchuenguem, 2005). For the second parameter, the number of times that the bee left this Solanaceae flowers to another plant species and vice versa was noted through the investigation period (Tchuenguem, 2005).

During each observation date, temperature and relative humidity in the station were registered every 30 minutes using a mobile thermo-hygrometer installed in the shade (Tchuenguem, 2005), from 6 a.m. to 6 p.m.

Evaluation of the apicultural value of Solanum nigrum

The beekeeping value of Solanum nigrum was assessed using data on its flowering intensity and the attractiveness of workers of A. mellifera to its pollen and nectar (Tchuenguem et al., 2008; Wekéré et al., 2020).

\section{Evaluation of the impact of flowering insects including Apis mellifera on Solanum nigrum yields}

Parallel to the implementation of treatments 1, 2, 5 and 6, 600 flowers at bug stage were labelled in 2019 and in 2020, to form two treatments:

- Treatment 3 in 2019 or 7 in 2020: 200 flowers protected using gauze bag nets to prevent insect or any other organism visits and destined to be visited exclusively by $A$. mellifera; as soon as each flower of these treatments was opened, the gauze bag was delicately removed and this flower was observed for up to 10 minutes; the flower visited once by $A$. mellifera was then reprotected (Tchuenguem and Népide, 2018);

- Treatment 4 in 2019 or 8 in 2020: 100 flowers protected using gauze bag nets and destined to be uncovered then rebagged without the visit of insects or any other organism (Diguir et al., 2020); as soon as each flower of these treatments was opened, the gauze bag was removed and this flower was observed for up to 10 minutes, while avoid 
insect or any other organism visits (Diguir et al., 2020).

At the maturity, fruits were harvested and counted from each treatment. The fruiting rate, the number of seeds per fruit and the percentage of normal (well developed) seeds were then determined for each treatment (Tchuenguem et al., 2009b). The evaluation of the effect of insects including A. mellifera on $S$. nigrum production was based on the impact of flowering insects on pollination, the impact of pollination on $S$. nigrum fruiting, and the comparaison of the fruiting rate, the number of seeds per fruit and the percentage of normal seeds of treatments 1, 2, 4, 5, 6 and 8. For each year, the fruiting rate due to the foraging insects including A. mellifera (Fri) was calculated using the following formula (Diguir et al., 2020): $\boldsymbol{F r i}=\{[(\boldsymbol{F} \boldsymbol{X}-\boldsymbol{F Z}) /(\boldsymbol{F} \boldsymbol{X}+\boldsymbol{F} \boldsymbol{Y}-$ $F Z)] \times 100\}$, where $F X, F Y$ and $F Z$ are the fruiting rates in treatment $X$ (flowers left in free pollination), treatment $Y$ (flowers protected from all insect visits) and treatment $Z$ (flowers bagged then uncovered and rebagged without insect or any other organism visit). The fruiting rate of a treatment $(F r)$ is $\boldsymbol{F r}=[(\boldsymbol{b} / \boldsymbol{a}) \times \mathbf{1 0 0}]$, where $b$ is the number of fruits formed and $a$ the number of viable flowers initially set (Tchuenguem et al., 2001). The impact of flower visiting insects including A. mellifera on the number of seeds per fruit and the percentage of normal seeds was evaluated using the same method as mentioned above for the fruiting rate.

\section{Assessement of the pollination efficiency of Apis mellifera on Solanum nigrum}

The contribution of A. mellifera on the fruiting rate, the number of seeds per fruit and the percentage of normal seeds was calculated using the data of treatments 3 and 4 for 2019 and those of treatments 7 and 8 for 2020. For each observation year, the contribution of $A$. mellifera on the fruiting rate $(F r A)$ was calculated using the following formula: $\boldsymbol{F r} \boldsymbol{A}=$ $\{[(\boldsymbol{F A}-\boldsymbol{F Z}) / \boldsymbol{F A}] \times \mathbf{1 0 0}\}$, where $F A$ is the fruiting rate in treatment $A$ (flowers bagged then uncovered, visited exclusively by $A$. mellifera and rebagged) (Djakbé et al., 2017). The impact of A. mellifera on the fruiting rate, the number of seed per fruit and the percentage of normal seeds were evaluated using the same method as mentioned above for the fruiting rate.

\section{Data analysis}

Statistical analyses were performed using: R commander; version i386 3.2.0.; descriptive statistics; Microsoft Excel 2010; ANOVA $(F)$ for the general comparison of means of more than two samples; student's $t$ test for the comparison of means of two samples, Pearson correlation coefficient $(r)$ for the study of the association between two variables; chi-square $\left(\chi^{2}\right)$ for the comparison of percentages.

\section{RESULTS}

\section{Reproduction mode of Solanum nigrum}

The fruiting indexes of $S$. nigrum were $0.92,0.81,0.9$ and 0.8 for treatments $1,2,5$ and 6 respectively. Thus, in 2019, the allogamy rate was $11.96 \%$ whereas the autogamy rate was $88.04 \%$. In 2020 , the corresponding figures were $11.11 \%$ and $88.89 \%$. For the two cumulated years, the allogamy rate was $11.54 \%$ and the autogamy rate was $88.46 \%$. It appears that $S$. nigrum has a mixed reproduction mode that is allogamous autogamous breeding regime, with the predominance of autogamy over allogamy.

\section{Place of Apis mellifera in Solanum nigrum floral entomofauna}

Among the 694 and 1958 visits of 17 and 25 insect species recorded on S. nigrum flowers in 2019 and 2020 respectively, A. mellifera ranked first with 288 visits $(41.50 \%)$ and 618 visits $(31.56 \%$ ), in 2019 and 2020 , respectively (Table 1 ). The difference between the percentages of A. mellifera visits for two years is highly significant $(\chi 2=25.08 ; \mathrm{df}=1$; $\mathrm{P}<0.001)$.

\section{Activity of Apis mellifera on Solanum nigrum flowers \\ Floral product harvested}

From field observations, A. mellifera workers were found to collect pollen (Figure 1) and nectar regulary and intensively on $S$. 
nigrum flowers. For 792 and 730 visits counted on these flowers in 2019 and 2020 respectively, $721(91.04 \%)$ and $620(84.93 \%)$ were for pollen collection whereas $71(8.96 \%)$ and 110 $(15.07 \%)$ were for nectar collection, respectively in 2019 and 2020. For the total of 1522 visits recorded during the two seasons, the number of visits allocated to pollen harvest was $1341(88.11 \%)$ and that for nectar collection was 181 (11.89\%) (Table 2).

\section{Rythm of visits according to the flowering stages}

Apis mellifera visits were most numerous in the $S$. nigrum field when the number of opened flowers was highest. Furthermore, a positive and significant correlation was found between the number of A. mellifera visits and the number of $S$. nigrum opened flowers in $2019(r=0.69 ; d f=4 ; P<$ $0.01)$ (Figure $2 \mathrm{~A})$ as well as in $2020(r=0.99$; $d f=4 ; P<0.01$ ) (Figure 2B). This result highlights the good attractiveness of the pollen and nectar of S. nigrum towards A. mellifera.

\section{Daily rythm of visits}

Apis mellifera foraged on S. nigrum flowers throughout the blooming period, with a peak of activity between 8 a.m. and 9 a.m. in 2019 as well as in 2020. Ambiant temperature and relative humidity did not influenced the activities of A. mellifera on $S$. nigrum (Figure $3)$. In 2019, the correlation was not significant $(r=-0.22 ; d f=2 ; P>0.05)$ between the number of $A$. mellifera visits and the temperature, and between the same number of visits and the relative humidity $(r=0.33 ; d f=$ $2 ; P>0.05$ ) (Figure 3A). In 2020, the correlation was equally not significant $(r=$ $0.4 ; d f=2 ; P>0.05)$ between the number of $A$. mellifera visits and the temperature, and beetwen the same number of visits and the relative humidity $(r=0.76 ; d f=2 ; P>0.05)$ (Figure 3B).

\section{Abundance of Apis mellifera}

In 2019, the highest mean number of $A$. mellifera workers simultaneous in activity was 1 per flower $(n=536 ; s=1.44)$ and 515.50 per 1000 flowers $(n=536 ; s=282.99)$. In 2020, the corresponding figures were 1 per flower $(n=$ $399 ; s=1.46)$ and 523.43 per 1000 flowers $(n$ $=399 ; s=287.34)$. There is no difference between these two means $(t=0.42 ; d f=943 ; P$ $>0.05$ ). For the two cumulated years the mean number of foragers per 1000 flowers was $519.46(n=935 ; s=285.16)$.

\section{Duration of visits per flower}

In 2019, the mean duration of a visit was $7.97 \mathrm{sec}(\mathrm{n}=71 ; \mathrm{s}=3.72 ;$ maxi $=21)$ for nectar collection, against $8.35 \mathrm{sec}(\mathrm{n}=721 ; \mathrm{s}=3.73$; maxi $=49$ ) for pollen harvest. The difference between the duration of a visit for nectar and pollen harvest in 2019 is not significant $(t=$ 0.82; $d f=790 ; P>0.05)$. In 2020, the corresponding figures were $7.82 \mathrm{sec}(\mathrm{n}=110$; $\mathrm{s}=2.84 ;$ maxi $=21)$ for nectar, against $8.2 \mathrm{sec}$ $(n=620 ; s=3.76 ; \operatorname{maxi}=68)$ for pollen. The difference between the duration of a visit for nectar and pollen harvest in 2020 is equally not significant $(t=1.22 ; d f=728 ; P>0.05)$. The difference between the duration of a visit for nectar harvest in 2019 and 2020 is not significant $(t=0.04 ; d f=179 ; P>0.05)$, the difference between the duration of a visit for pollen collection in 2019 and 2020 is equally not significant $(t=0.04 ; d f=1339 ; P>0,05)$. For the two cumulated years, the mean duration of a flower visit was $7.89 \mathrm{sec}(\mathrm{n}=181$; $\mathrm{s}=3.28)$ for nectar collection and $8.27 \mathrm{sec}(\mathrm{n}=$ $1341 ; \mathrm{s}=3.74$ ) for pollen harvest. The difference between these two later means is not significant $(t=0.10 ; d f=1520 ; P>0.05)$.

\section{Foraging speed}

In $S$. nigrum field, the mean foraging speed of A. mellifera was 9.25 flowers per minute $(n=85 ; s=3.61)$ in 2019 and 11.54 flowers per minute $(n=60 ; s=3.89)$ in 2020 . The difference between these two means is highly significant $(t=21.45, d f=143 ; P<$ $0.001)$. For the two cumulated years, the mean foraging speed was 10.39 flowers per minute ( $n$ $=145 ; s=3.75)$ (Table 2).

\section{Influence of fauna}

Workers of A. mellifera were disturbed in their foraging activity by other foragers of the same species or those from other species that were the competitor for $S$. nigrum nectar and / or pollen. In 2019, for 288 visits of $A$. mellifera, $2(0.69 \%)$ were interrupted by $A$. mellifera and $5(1.73 \%)$ by Xylocopa sp. 1. In 2020, for 618 visits, $4(0.64 \%)$ were interrupted 
by A. mellifera and $8(1.29 \%)$ by Xylocopa sp. 1.

\section{Influence of neighbouring flora}

During the flowering period of $S$. nigrum, flowers of many other plant species surrounding the field of this Solanaceae were visited by A. mellifera, for nectar (ne) and / or pollen (po) (Table 3). During the two years of study, we observed no passage of A. mellifera from $S$. nigrum flowers to flowers of another plant species and vice versa. Hence during foraging trips on $S$. nigrum, individuals of $A$. mellifera were faithful to this Solanaceae.

\section{Apicultural value of Solanum nigrum}

During the observation periods of flowering of $S$. nigrum, a well elaborated activity of A. mellifera workers was registered on its flowers. In particular, there were a good daily and seasonal frequency of visits, high density of workers per 1000 flowers, very good nectar and pollen harvest, fidelity of the workers to the flowers. These data highlight the good attractiveness of $S$. nigrum nectar and pollen to A. mellifera. Therefore, S. nigrum is a highly polliniferous and nectariferous bee plant.

\section{Impact of anthophilous insects including Apis mellifera on Solanum nigrum yields}

The fruiting rate, the mean number of seeds per fruit and the percentage of normal seeds in the different treatments of $S$. nigrum are shown in Table 4.

This table shows that :

a) The fruiting rate was $91.67 \%$, $80.83 \%, 83.55 \%, 68,99 \%, 79.29 \%, 73.47 \%$, $80.59 \%$ and $67.09 \%$ in treatments 1 to 8 respectively. The differences between these eight percentages are globally hightly significant $\left(\chi^{2}=253.52 ; d f=7 ; P<0.001\right)$. The two-to-two comparaisons showed that the difference observed is highly significant between treatments 1 and $2\left(\chi^{2}=5.96 ; d f=1\right.$; $P<0.001)$, as well as between treatments 5 and $6\left(\chi^{2}=4.72 ; d f=1 ; P<0.001\right)$. Consequently, in 2019 and 2020, the fruiting rate of unprotected flowers (treatments 1 and 5) was higher than that of protected flowers (treatments 2 and 6).

b) The mean numbers of seeds per fruit were $79.14,73.40,80.59,66.99,79.30,73.48$, 80.59 and 67.09 in treatments 1 to 8 respectively. The differences between these eight means are globally hightly significant $(F$ $\left.=846.44 ; d f_{1}=7 ; d f_{2}=798 ; P<0.001\right)$. The two-to-two comparaisons showed that the difference observed is hightly significant between treatments 1 and $2(t=49.72 ; d f=$ 205; $P<0.001)$, as well as between treatments 5 and $6(t=47.42 ; d f=202 ; P<0.001)$. Consequently in 2019, as well as in 2020, the mean number of seeds per fruit of unbagged flowers (treatments 1 and 5) was higher than that of bagged flowers (treatments 2 and 6).

c) The percentages of normal seeds were $97.74 \%, 94.82 \%, 91.84 \%, 86.64 \%, 97.76 \%$, $94.83 \%, 96.62 \%$ and $94.79 \%$ in treatments 1 to 8 respectively. The differences between these eight percentages are globally hightly significant $\left(\chi^{2}=49.57 ; d f=7 ; P<0.001\right)$. The two-to-two comparaisons showed that the difference observed is highly significant between treatments 1 and $2\left(\chi^{2}=96.79 ; d f=1\right.$; $P<0.001)$, as well as between treatments 5 and $6\left(\chi^{2}=96.71 ; d f=1 ; P<0.001\right)$. Hence, in 2019 as well as in 2020 , the percentage of normal seeds of exposed flowers (treatments 1 and 5) was higher than that of bagged flowers (Treatments 2 and 4).

In 2019, the numeric contribution of anthophilous insects in the fruiting rate, the mean number of seeds per fruit and the percentage of normal seeds of $S$. nigrum were $12.84 \%, 6.56 \%$ and $8.29 \%$ respectively. In 2020 , the corresponding figures were $12 \%$, $6.53 \%$ and $0.07 \%$. For the two cumulated years, the numeric contribution of anthophilous insects including A. mellifera were $12.42 \%$, $6.54 \%$ and $4.18 \%$ for the fruiting rate, the mean number of seeds per fruit and the percentage of normal seeds of $S$. nigrum respectively.

\section{Pollination efficiency of Apis mellifera on Solanum nigrum}

During a single flower visit of $A$. mellifera for nectar or pollen harvest on $S$. 
nigrum flowers, this bee always came into contact with anthers and stigma, increasing the possibility of this Solanaceae pollination.

The comparaison of fruiting rates (Table 5) shows that the difference observed was highly significant between treatments 3 and $4\left(\chi^{2}=11.63 ; d f=1 ; P<0.001\right)$, as well as between treatments 7 and $8\left(\chi^{2}=9.96 ; d f=\right.$ $1 ; P<0.001)$.

The comparison of the mean numbers of seeds per fruit (Table 5) shows that the difference observed was significant between treatments 3 and $4(t=2.02 ; d f=195 ; P<$ $0.05)$, as well as between treatments 7 and $8(t$ $=2.05 ; d f=193 ; P<0.05)$.

The comparaison of the percentage of normal seeds (Table 5) shows that the difference observed was highly significant between treatments 3 and $4\left(\chi^{2}=25.10 ; d f=1\right.$; $P<0.001)$, as well as between treatments 7 and $8\left(\chi^{2}=29.36 ; d f=1 ; P<0.001\right)$.

Hence, in 2019 and 2020, the fruiting rate, the mean number of seeds per fruit and the percentage of normal seeds of flowers visited once by A. mellifera was higher than that of flowers bagged then uncovered and rebagged without insect or any other organism visit.

In 2019, the numeric contribution of $A$. mellifera on the fruiting rate, the percentage of the number of seeds per fruit and the percentage of normal seeds were $16.29 \%$, $5.19 \%$ and $15.63 \%$ respectively. In 2020 , the corresponding figures were $16.66 \%, 1.06 \%$ and $15.52 \%$ respectively. For the two cumulated years, the corresponding figures were $16.29 \%, 3.45 \%$ and $15.57 \%$ respectively.

Table 1: List of insects collected on Solanum nigrum flowers in 2019 and 2020 at Meskine, number and percentage of visits of different insects.

\begin{tabular}{|c|c|c|c|c|c|c|c|c|}
\hline \multicolumn{3}{|l|}{ Insects } & \multicolumn{2}{|c|}{2019} & \multicolumn{2}{|c|}{2020} & \multicolumn{2}{|c|}{ Total } \\
\hline Order & Family & Genus and species & $n_{1}$ & $p_{1}(\%)$ & $n_{2}$ & $p_{2}(\%)$ & $n_{t}$ & $p t(\%)$ \\
\hline \multirow[t]{2}{*}{ Coleoptera } & & (sp. 1) (ne, po) & - & - & 4 & 0.20 & 4 & 0.15 \\
\hline & Scarabeidae & $(1 \mathrm{sp}).(\mathrm{ne}, \mathrm{po})$ & - & - & 1 & 0.05 & 1 & 0.04 \\
\hline \multirow[t]{2}{*}{ Diptera } & Muscidae & Chrysomia chloropyga (ne) & 2 & 0.29 & 3 & 0.15 & 5 & 0.19 \\
\hline & Syrphidae & $(1 \mathrm{sp}).(\mathrm{ne}, \mathrm{po})$ & - & - & 6 & 0.31 & 6 & 0.23 \\
\hline \multirow[t]{13}{*}{ Hymenoptera } & Apidae & Apis mellifera (ne, po) & 288 & 41.50 & 618 & 31.56 & 906 & 34.16 \\
\hline & & Amegilla calens (ne) & 14 & 2.02 & 205 & 10.47 & 219 & 8.26 \\
\hline & & Amegilla sp. 1 (ne, po) & 2 & 0.29 & 74 & 3.78 & 76 & 2.87 \\
\hline & & Amegilla sp. 2 (ne, po) & 5 & 0.72 & 2 & 0.10 & 7 & 0.26 \\
\hline & & Amegilla sp. 3 (ne, po) & 2 & 0.29 & 3 & 0.15 & 5 & 0.19 \\
\hline & & Braunsapis sp. (ne, po) & 77 & 11.10 & 156 & 7.97 & 233 & 8.79 \\
\hline & & Ceratina sp. 1 (ne, po) & 6 & 0.86 & - & - & 6 & 0.23 \\
\hline & & Ceratina sp. 2 (po) & 4 & 0.58 & - & - & 4 & 0.15 \\
\hline & & Xylocopa olivacea (ne, po) & 20 & 2.88 & 101 & 5.16 & 121 & 4.56 \\
\hline & & Xylocopa sp. 1 (ne, po) & 197 & 28.39 & 467 & 23.85 & 664 & 25.04 \\
\hline & & Xylocopa sp. 2 (ne, po) & 5 & 0.72 & 17 & 0.87 & 22 & 0.83 \\
\hline & Formicidae & Camponotus brutus (ne) & - & - & 105 & 5.36 & 105 & 3.96 \\
\hline & & Polyrachis sp. (ne, po) & - & - & 4 & 0.20 & 4 & 0.15 \\
\hline
\end{tabular}




\section{Halictidae (1 sp.)}

Lasioglossum sp. 1 (ne, po)

Lasioglossum sp. 2 (ne, po)

Lipotriches azarensis (ne, po)

Megachilidae (1 sp.)

Vespidae

Amophilia sabulosa (ne, po )

Belonogaster juncea (ne)

Sceliphron sp. (ne, po )

Lepidoptera Papilionidae Acraea acerata (ne)

Pieridae
Eurema sp. (ne)

5

:

\section{TOTAL}

$\boldsymbol{n}_{\boldsymbol{1}}$ and $\boldsymbol{n}_{2}$ : number of visits on 120 flowers in 2019 and 2020; $\boldsymbol{p}_{\boldsymbol{1}}$ and $\boldsymbol{p}_{2}$ : percentages of visits in 2019 and 2020; sp.: undetermined species; ne: collection of nectar; po: collection of pollen; $p_{1}=\left(\mathrm{n}_{1} / 694\right) \times 100 ; \boldsymbol{p}_{2}=\left(\mathrm{n}_{2} / 1958\right) \times 100$.

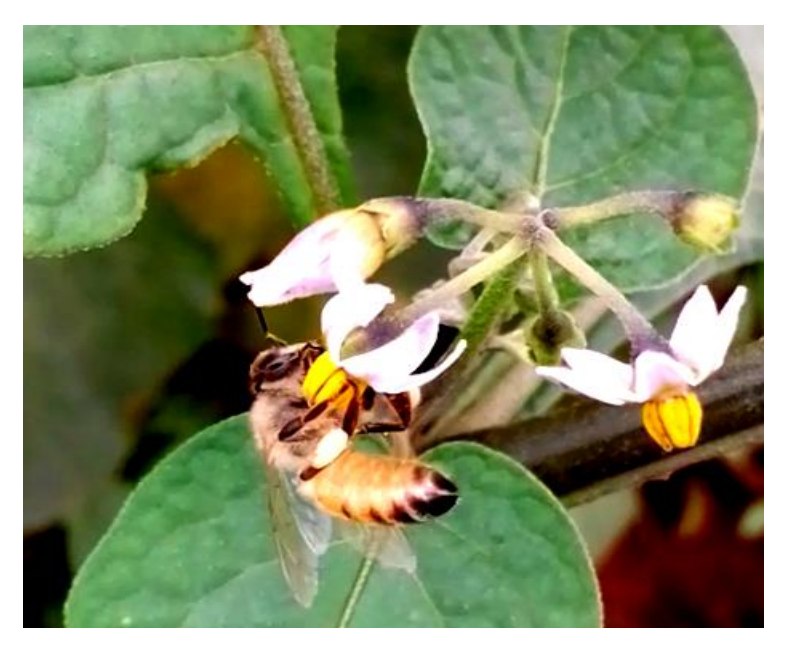

Figure 1: Apis mellifera worker collecting pollen from a Solanum nigrum flower at Meskine in 2019.

Table 2: Foraging speed of Apis mellifera on Solanum nigrum flowers in 2019 and 2020 at Meskine.

\begin{tabular}{|c|c|c|c|c|c|c|}
\hline \multirow{2}{*}{ Years } & \multicolumn{5}{|c|}{ Number of flowers visited per minute } & \multirow{2}{*}{ Comparison of means } \\
\hline & $n$ & $m$ & $s d$ & $\operatorname{mini}$ & $\operatorname{maxi}$ & \\
\hline 2019 & 85 & 9.25 & 3.61 & 4 & 25 & \multirow{2}{*}{$t=(21.45 ; d f=143 ; P<0.001) \mathrm{VHS}$} \\
\hline 2020 & 60 & 11.54 & 3.89 & 5 & 25 & \\
\hline Total & 145 & 10.39 & 3.75 & 4 & 25 & \\
\hline
\end{tabular}

$\boldsymbol{n}$ : number of visits studied; $\boldsymbol{m}$ : mean; $\boldsymbol{s d}$ : standard deviation; mini: minimum; maxi: maximum; $d f$ : degre of freedom; VHS: very highly significant difference. 

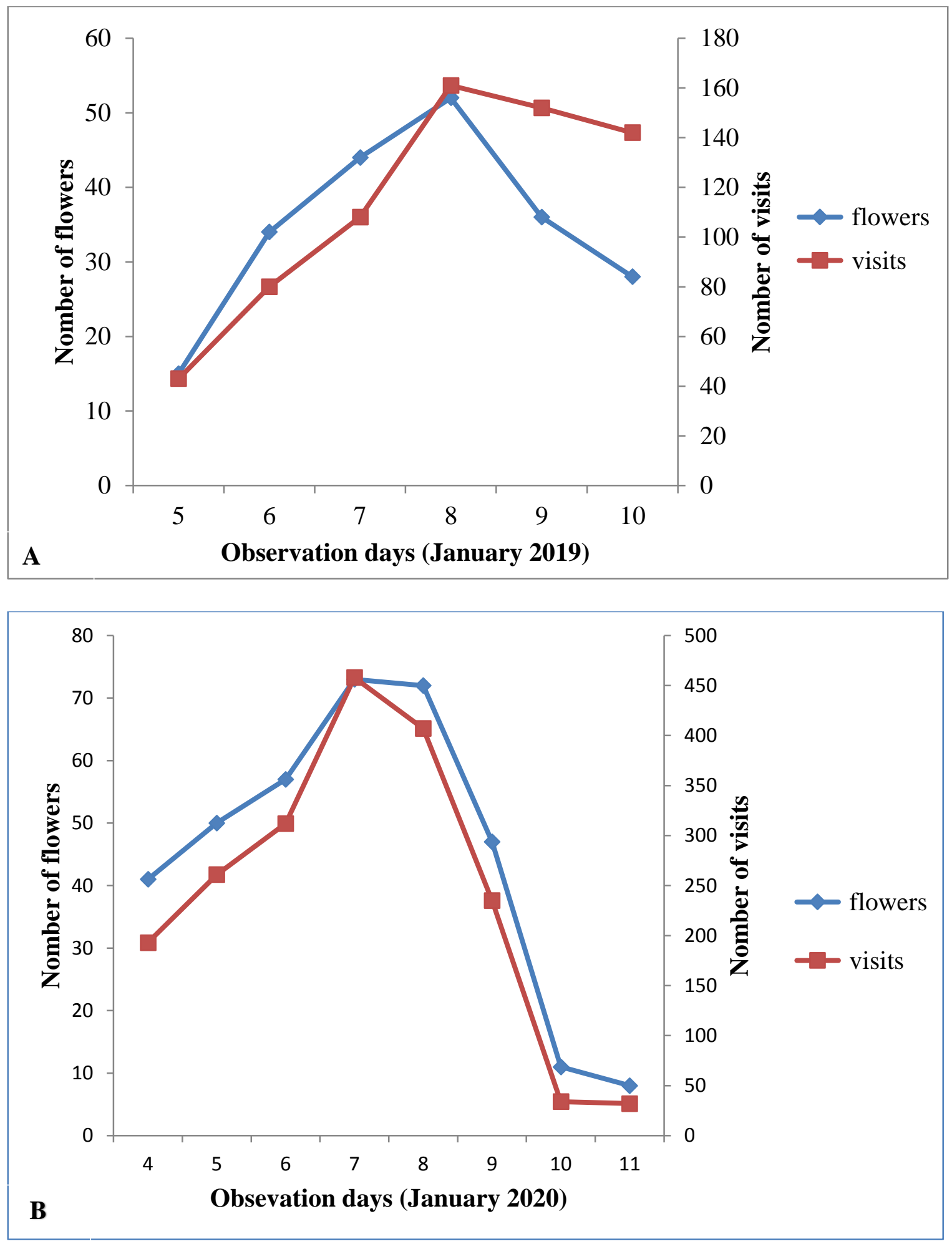

Figure 2: Seasonal variations of the number of Solanum nigrum opened flowers and the number of Apis mellifera visits on these organs in 2019 (A) and 2020 (B) at Meskine. 

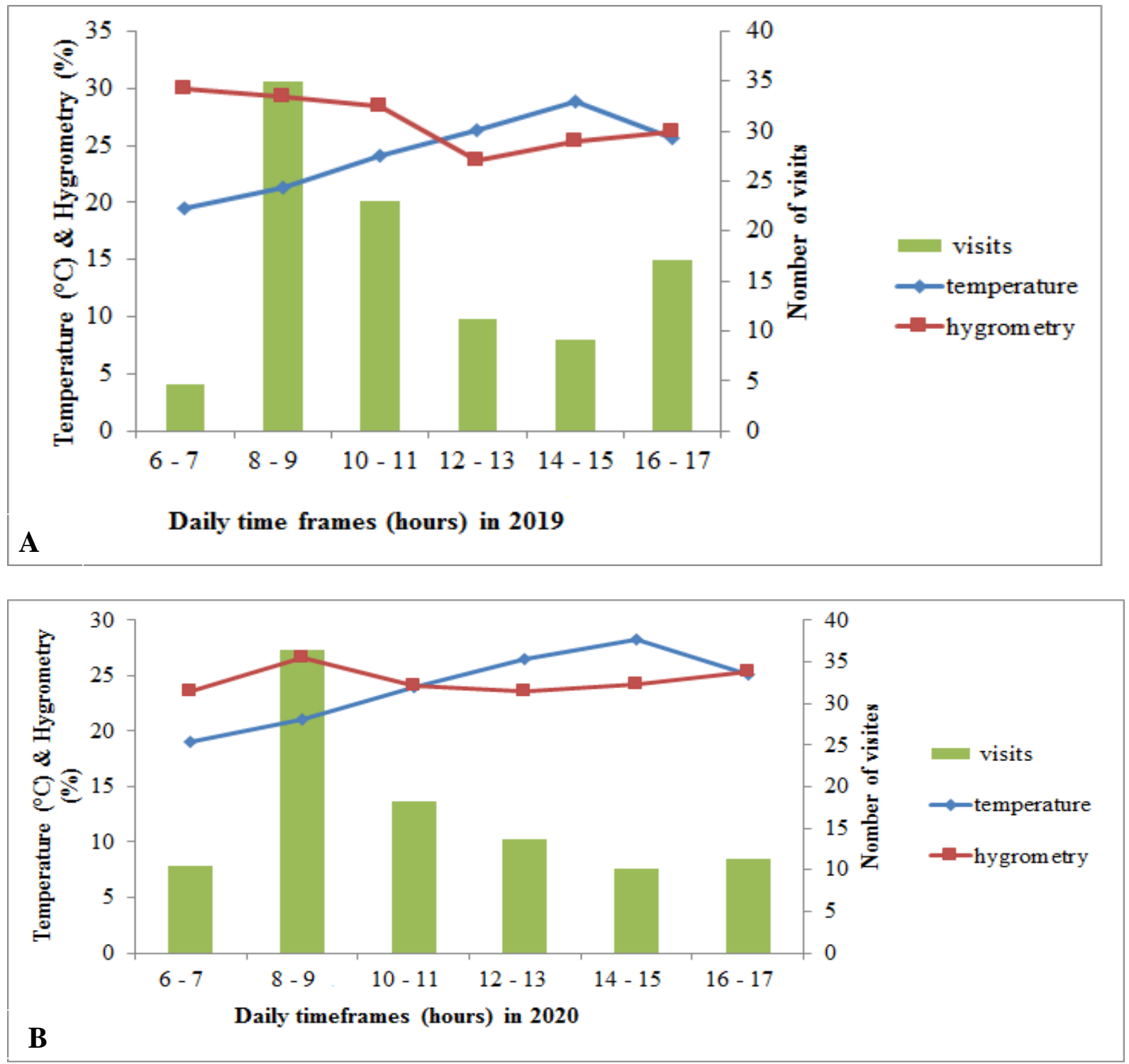

Figure 3: Variations of the temperature, the humidity and the number of Apis mellifera visits on Solanum nigrum flowers according to the daily time frames in 2019 (A) and 2020 (B) at Meskine.

Table 3: Plant species surrounding Solanum nigrum, floral products and intensity of harvesting by Apis mellifera in 2019 and 2020 at Meskine.

\begin{tabular}{llcc}
\hline \multirow{2}{*}{ Plant species } & \multirow{2}{*}{ Family } & \multicolumn{2}{c}{ Floral products } \\
\cline { 3 - 4 } & & Nectar & Pollen \\
\hline Solanum lycopersicum & Salanaceae & + & +++ \\
Mangifera indica & Anacardiaceae & ++ & + \\
Cosmos sulphureus & Asteraceae & + & +++ \\
Luffa cylindrica & Curcubitaceae & +++ & ++ \\
Gossypium hirsutum & Malvaceae & +++ & + \\
Hibiscus sabdariffa & Malvaceae & + & +++ \\
\hline
\end{tabular}

+ = low collection; ++ = high collection; +++ = very high collection. 
Table 4: Fruiting rate, mean number of seeds per fruit and percentage of normal seeds in the different treatments of Solanum nigrum in 2018 and 2019 at Meskine.

\begin{tabular}{|c|c|c|c|c|c|c|c|c|c|c|}
\hline \multirow{2}{*}{ Years } & \multirow{2}{*}{ Treatments } & \multirow{2}{*}{ NFS } & \multirow{2}{*}{ NFF } & \multirow{2}{*}{ FR $(\%)$} & \multicolumn{3}{|c|}{ Seeds/fruit } & \multirow[t]{2}{*}{ TNS } & \multirow[t]{2}{*}{ NNS } & \multirow[t]{2}{*}{$\% \mathrm{NS}$} \\
\hline & & & & & $m$ & $s d$ & $n$ & & & \\
\hline \multirow{4}{*}{2019} & 1 (Uf) & 120 & 110 & 91.67 & 79.14 & 4.97 & 110 & 8705 & 8508 & 97.74 \\
\hline & $2(\mathbf{P f})$ & 120 & 97 & 80.83 & 73.40 & 6.76 & 97 & 7120 & 6751 & 94.82 \\
\hline & 3 (Fpva) & 105 & 93 & 83.55 & 80.59 & 4.21 & 93 & 7495 & 7245 & 91.84 \\
\hline & 4 (Fpwv) & 148 & 104 & 68.24 & 66.99 & 8.12 & 104 & 6967 & 6619 & 86.64 \\
\hline \multirow{4}{*}{2020} & 5 (Uf) & 120 & 108 & 90 & 79.30 & 4.90 & 108 & 8564 & 8372 & 97.76 \\
\hline & 6 (Pf) & 120 & 96 & 80 & 73.48 & 6.79 & 96 & 7054 & 6689 & 94.83 \\
\hline & 7 (Fpva) & 110 & 93 & 83.55 & 80.59 & 4.23 & 93 & 7495 & 7242 & 96.62 \\
\hline & 8 (Fpwv) & 152 & 102 & 68.24 & 67.09 & 7.89 & 102 & 6844 & 6488 & 94.79 \\
\hline
\end{tabular}

Uf: unprotected flowers; Pf: protected flowers; Fpva: flowers protected then uncovered, visited once by Apis mellifera and reprotected; Fpwv: flowers bagged then uncovered and rebagged without visit by insect or any other organism; NFS: number of flowers studies; NFF: number of fruits formed; FR: Fruiting rate; TNS: total number of seeds; NNS: number of normal seeds; \%NS: percentage of normal seeds.

\section{DISCUSSION}

\section{Place of Apis mellifera in the Solanum nigrum floral entomofauna}

Results obtained from the experiments indicated that among insect species reccorded on S. nigrum flowers, A. mellifera was the most represented insect with 288 visits (41.44\%) in 2019 and 618 visits (31.01\%) in 2020. Bees and flies in Britain (Edmonds and Chweya, 1997) and Magachile latimanus in Nigeria (Oyelana and Ogunwenmo, 2012) have respectively been described as the main pollinators of Solanum crop species. Apis mellifera was shown to be the most floral visitor of other plant species including Helianthus annuиs (Egono et al., 2018), Vitellaria paradoxa (Basga et al., 2018), Luffa cylindrica (Farda and Tchuenguem, 2018), Sesamum indicum (Mahfouz et al., 2012; Pando et al., 2013) and Physalis minima (Basualdo et al., 2000). The significant difference between the frequencies of $A$. mellifera visits and those of other insects can be explained by the strategies adopted by this bee that consist of recruiting a great number of workers for the exploitation of an interesting nutritional source (von Frisch, 1969;
Louveaux, 1984; Kajobe, 2006). Consequently, there may be a limitation of the number of visits of other insect species due to the occupation of the majority of open flowers by A. mellifera workers.

\section{Activity of Apis mellifera on Solanum nigrum flowers}

The fact that nectar collection occurred early in the morning whereas pollen collection occurred throughout the day is in agreement with the observations of Schippers (1998) who mentioned that anthers of Solanum flowers may still contain a large amount of pollen on the second day of anthesis. The activity of the honeybee was high in the morning, with a peak situated between 8 and 9 a.m., which is the daily period of hightest availability of nectar and pollen in the flower of $S$. nigrum.

The positive and significant correlation between the number of opened flowers and the number of visits in 2019, as well as in 2020 indicates the good attractiveness of $S$. nigrum nectar and / or pollen with respect to $A$. mellifera. This result corroborates those of Faegri and Pijl (1979) which indicate that the number of opened flowers is an essential factor 
which plays an important role in guiding insects towards the flowers.

The high density of workers per 1000 flowers recorded in this study could be due to the natural faculty of honeybees to recruit a high number of workers to exploit an interesting food source (Louveaux, 1984). Honeybees can smell or detect pollen or nectar odors (Free, 1970) using sensory receptors located on the flagellum of their antennae (Free, 1970). In fact, honeybees dance inside the nest after a successful foraging trip in other to communicate to their nest mate's information concerning the food odor, the distance and the direction from the hive to the food source (Frisch, 1967).

The disruption of visits by other insects reduced the duration of certain A. mellifera visits. This obliged some workers to visit more flowers during a foraging trip to maximize their pollen or nectar loads. Similar observations have been made in A. mellifera workers foraging on the flowers of: Physalis minima (Djakbé et al., 2017); Sesamum indicum (Otiobo et al., 2016; Tchuenguem and Népidé, 2018) and Solanum nigrum (Basualdo et al., 2000).

The present study revealed that during one foraging trip, an individual bee foraging on a given plant species scarcely visited another plant species. This result indicates that $A$. mellifera showed flower constancy (Basualdo et al., 2000) on $S$. nigrum. The fidelity of $A$. mellifera has been demonstrated on flowers of several other plant species including Physalis minima (Djakbé et al., 2017), Sesamum indicum (Otiobo et al., 2016; Tchuenguem \& Népidé, 2018), Helianthus annuus (Basualdo et al., 2000; Egono et al., 2018) and Vigna unguiculata (Djonwangwé et al., 2017)

\section{Impact of anthophilous insects including Apis mellifera on Solanum nigrum yields}

The flowers that were exposed to visits provided more fruits and more seeds than protected flowers, in agreement with the previous results reported on $S$. nigrum in Nigeria (Oyelana and Ogunwenmo, 2012). The significant increase in fruit production in the presence of flowering insects including $A$. mellifera is the consequence of their foraging activity on the pollination of the visited flowers.

The significant contribution of $A$. mellifera and other insects in the fruit $(12,42 \%)$ and seed $(4,18 \%)$ yields of $S$. nigrum is in agreement with the findings in Ghana (Amoako and Yeboah-Gyam, 1991) and Nord West Region of Cameroon (Otiobo et al., 2015) where solanaceous crops produce less seeds per fruit in the absence of efficient pollinators.

\section{Pollination efficiency of Apis mellifera on Solanum nigrum}

During the collection of nectar or pollen on each flower, A. mellifera workers regularly come into contact with the stigma and anthers. They could thus enhance self-pollination, which has been demonstrated in the past (Edmonds and Chweya, 1997), by applying pollen of one flower on its stigma. Apis mellifera could provide allogamous pollination through carrying of pollen within their hairs, silk, legs, mouthparts, thorax and abdomen, which is then deposited on flowers belonging to a different plant of the same species (geitonogamy) (Edmonds and Chweya, 1997). The positive and significant contribution of $A$. mellifera in the fruiting rate, the percentage of normal seeds of $S$. nigrum is justified by the action of this bee on the pollination of visited flowers.

\section{Conclusion}

At Meskine (Maroua, Cameroon), Solanum nigrum is a plant that benefits from the pollination by insects among whitch Apis mellifera was the most important and harvested nectar and pollen. The comparaison of fruit and seed sets of flowers protected then uncovered, visited once by $A$. mellifera and rebagged to those of flowers protected from insects then 
uncovered and rebagged without the visit of insects or any other organism underscores the value of this bee in increasing the fruiting rate $(16.29 \%)$, the percentage of the number of seeds per fruit $(3.45 \%)$ and the percentage of normal seeds $(15.57 \%)$. Solanum nigrum is a highly polliniferous and nectariferous bee plant that could be cultivated and protected to increase pollen yield as a hive product, improve honey production and strengthen $A$. mellifera colonies. The installation of $A$. mellifera colonies at the vicinity of $S$. nigrum fields is recommended to increase fruit quantity and seed production. Furthermore, insecticide and / or herbicide treatments should be avoided in the field of $S$. nigrum during its flowering period. If these treatments are necessary, the choice of the insecticides that are less toxic for bees or the integrated pest control should be recommended to protect pollinating insects such as A. mellifera.

\section{COMPETING INTERESTS}

The authors declared that they have no competing interests for this article.

\section{AUTHORS' CONTRIBUTIONS}

JM was the main investigator. $\mathrm{He}$ collected data in the field and contributed to bibliographic research, preliminary insect determination and data analysis. SFT designed the project and FNTF supervised it. Both contributed to bibliographic research, insect identification and data analysis. EB contributed to bibliographic research, insect identification and data analysis. Each of these authors participated in the drafting of the manuscript.

\section{ACKNOWLEDGEMENTS}

The authors thank all those who facilitated this work, especially the Agricultural Research Institute for Development of Maroua which provided us the plot for the experiment.

\section{REFERENCES}

Aboubakar A, Zing ZB, Nzeket AB, Moussima YDA, Tchudjo TAN, Mfopou MYC, Birang MCR. 2020. Effets des amendements sur la croissance, le rendement et la composition chimique de la morelle noire (Solanum nigrum L.) en zone périurbaine de Yaoundé, Cameroun. Int. J. Biol. Chem. Sci., 14(6): 2134-2146. DOI:

https://dx.doi.org/10.4314/ijbcs.v14i6.16

Abrol DP. 2012. Pollination Biology Biodiversity Conservation and Agricultural Production. Springer Dordrecht Heidelberg: London.

Agbo AE, Kouame C, Mahyao A, N'zi JC, Fondio L. 2009. Nutrition importance of indigenous leafy vegetable of Cote d'Ivoire. Acta Horticulturae, 806: 361366.

DOI:

http://dx.doi.org/10.4314/just.v35i2

Aleixo KP, Menezes C, Mperatriz FVL, Silva CI. 2017. Seasonal availability of floral resources and ambient temperature shape stingless bee foraging behavior (Scaptotrigona aff. depilis). Apidologie, 48: 117-127. DOI: http://dx.doi.org/10.1108/IJSHE-022017.0O16

Amoako J, Yeboah-Gyan K. 1991. Insect pollination of three solanaceous vegetable crops in Ghana with special reference to the hole of African honey bee (Apis mellifera adansonii) for fruit set. Acta Horticulturae, 288(38): 255-259.

Aseng CC, Tiako TEA, Okolle J, Ambang Z, Monkam TF. 2017. Effect of culture density of black nightshade (Solanum nigrum) on the insect infestation. Plant, 5(5-1): 19-26. DOI: 10.11648/j.plant.s.2017050501.13

Basga E, Fameni TS, Tchuenguem FFN. 2018. Foraging and pollination activities of Xylocopa olivacea (Hymenoptera: Apidae) on Vitallaria paradoxa (Sapotaceae) flowers at Ouro-Gadji 
(Garoua, Cameroon). J. Entomol. Zool. Stud., 6(3): 1015-1022. DOI: http://dx.doi.org/10.4314/jab.v138i1.11

Basualdo M, Bedascarrasbure E, De Jong D. 2000. Africanized honey bees (Hymenoptera: Apidae) have a greater fidelity to sunflowers than European honey bees. J. Econ. Entomol., 93(2): 304-307. DOI: https://doi.org/10.1603/0022-049393.2.304

Borror DJ, White RE. 1991. Les Insectes de l'Amérique du Nord (au Nord $d u$ Mexique) (ed). Laprairie: Paris.

Davidar P, Snow AA, Rajkumar M, Pasquet R, Daunay MC, Mutegi E. 2015. The potential for crop to wild hybridization in eggplant (Solanum melongena; Solanaceae) in southern India. Am. J. of Bot., 102(1): 129-139. DOI: http://dx.doi.org/10.3732/ajb.1400404

Demarly. 1977. Génétique et Amélioration des Plantes. Masson: Paris.

Deprá M, Geovana CGD, Leandro F, Maria CG. 2014. Pollination deficit in openfield tomato crops (Solanum lycopersicum; Solanaceae) in Rio De Janeiro state, Southeast Brazil. $J$. Pollinat. Ecol., 12(1): 1-8. DOI: 10.1007/s.10340-0591-5

Djakbé JD, Ngakou A, Christian W, Faïbawa E, Tchuenguem FFN. 2017. Pollination and yield components of Physalis minima (Solanaceae) as affected by foraging activity of Apis mellifera (Hymenoptera: Apidae) and compost at Dang (Ngaounéré, Cameroon). Int. J. Agron. Agri. $\quad R ., \quad$ 11(3): $\quad 43-60$. http://www.innspub.net

Diguir BB, Pando JB, Fameni TS, Tchuenguem FFN. 2020. Pollination efficiency of Dactylurina staudingeri (Hymenoptera: Apidae) on Vernonia amygdalina (Asteraceae) florets at Dang (Ngaoundéré, Cameroon). Int. J. Res. Stud. Agric. Sci., 6(2): 22-31. DOI: http://dx.doi.org/10.20431/24546224.0602004

Djonwangwé D, Pando JB, Kameni BSA, Mbonomo BM, Tchuenguem FFN, Messi J. 2017. Impact des activités de butinage de Xylocopa inconstans Smith F. 1874 (Hymenoptera: Apidae) et Megachile eurymera Smith 1864 (Hymenoptera: Megachilidae) sur la pollinisation et les rendements fruitier et grainier de Vigna unguiculata (L.) Walp. 1843 (Fabaceae) à Maroua, Extrême-Nord, Cameroun. Afr. Sci., 13(5): 1-17. DOI: https://doi.org/10.1093/jnci/djx029

Dounia K, Tchuenguem FFN. 2013. Foraging and pollination activity of Apis mellifera adansonii Latreille (Hymenoptera: Apidae) on flowers of Gossypium hirsutum L. (Malvaceae) at Maroua, Cameroon. Int. Res. J. Plant Sci., 4(2): 33-44.

DOI: http://dx.doi.org/10.4314/jab.v138i1.11

Duke JA, Ayensu ES. 1985. Medicinal plants of China. Brittonia, 37: 7-8. DOI: https://doi.org/10.1002/fedr.1987098070 7

Edmonds JM, Chweya JA. 1997. Black Nightshades: Solanum nigrum L. and related species. Int. Pl. Gen. Res. Inst., 15: 1-115.

Edmonds JM. 1979. Biosystematics of Solanum L. section Solanum (Maurella). In Biology and Taxonomy of the Solanaceae, Hawkes JG, Lester RN, Skelding AD (eds). Academic Press: London; 1-19.

Egono NCC, Kingha TBM, Fameni TS, Dounia, Tchuenguem FFN. 2018. Pollination efficiency of Apis mellifera (Hymenoptera: Apidae) on Helianthus annuиs (Asteraceae) flowers at Dang (Ngaoundéré, Cameroon) Int. J. Bio., 13(3): 314-328. DOI: 10. 5897/IJB

Farda D, Tchuenguem FFN. 2018. Efficacité pollinisatrice de Apis mellifera (Hymenoptera : Apidae) sur Luffa 
cylindrica (L.) M. Roem (Cucurbitaceae) à Ngaoundéré (Cameroun). Int. J. Biol. Chem. Sci., 12(2): 850-866. DOI: https://dx.doi.org/10.4314/ijbcs.v12i2.19

Free JB. 1993. Insect Pollination of Crops. Academic Press: London.

Frisch KV. 1969. Vie et Moeurs des Abeilles. Albin Michel: Paris.

Jacob-Remacle A. 1989. Comportement de butinage de l'abeille domestique et des abeilles sauvages dans des vergers de pommiers en Belgique. Apidologie, 20(4): 271-285.

Jean-Prost P. 1987. Apiculture: Connaître l'Abeille - Conduire le Rucher (6 ${ }^{\text {ème }} \mathrm{ed}$ ). Lavoisier: Paris.

Klein AM, Vaissière BE, Can JH, SteffanDewenter I, Cunningham SA, Kremen SE, Tscharntke T. 2007. Importance of pollisators on changing landscapes for world crops. Proc. Royal Soc., 273: 303313.

DOI: http://doi.org/10.1098/rspb.2006.3721

Letouzey R. 1968. Etude Phytogéographique $d u$ Cameroun ( $5^{\mathrm{ème}}$ ed). Paul Le Chevalier: Paris.

Louveaux J. 1984. L'abeille domestique dans ses relations avec les plantes cultivées. In Pollinisation et Productions Végétales, Pesson P, Louveaux J (eds). INRA: Paris; 527-555.

Mahfouz HM, Kamel SM, Belal AH, Said M. 2012. Pollinators visiting sesame (Sesamum indicum L.) seed crop with reference to foraging activity of some bee species. J. Agron. Res., 2(150): 4955. DOI: 10.2478/v10298-012-0014-9

Mohamadou M, Ngakou A, Tchuenguem FFN. 2018. Integrated impact of mycorrhiza (Glomussp) and pollinating insects on growth and yield of Vigna subterranea (L.) Verdcourd (Fabaceae). Int. J. Biol. Chem. Sci., 12(4): 18971913.

DOI: https://dx.doi.org/10.4314/ijbcs.v12i430
Olmstead RG, Bohs L, Migid HA, Eugenio SV, Vicente FG, Sarah MC. 2008. A molecular phylogeny of the Solanaceae. Taxon., 57(4): 1159-1181. DOI: https://doi.org/10.1002/tax.574010

Otiobo AEN, Tchuenguem FFN, Champlain DL. 2015. Foraging and pollination behavior of Apis mellifera adansonii (Hymenoptera: Apidae) on Physalis micrantha (Solanales: Solanaceae) flowers at Bambui (Nord-West, Cameroon). J. Entomol. Zool. Stud., 3(6): 250-256.

Otiobo AEN, Tchuenguem FFN, Champlain DL. 2016. Diversité de l'entomofaune floricole de Sesamum indicum (L.) 1753 (Pedaliaceae) et son impact sur les rendements fruitiers et grainiers à Bambui (Nord-Ouest, Cameroun). Int. J. Biol. Chem. Sci., 10(1): 106-119. DOI: http://dx.doi.org/10.4314/ijbcs.v10i1.8

Oyelana OA, Ogunwenmo KO. 2012. Floral biology and the effects of plantpollinator interaction on pollination intensity, fruit and seed set in Solanum. Afric. J. Biotech., 11(84): 14967-14981.

Pando JB, Tchuenguem FFN, Tamesse JL. 2013. Activité de butinage et de pollinisation de Xylocopa olivacea Fabricius 1787 (Hymenoptera: Apidae) sur les fleurs de Vigna unguiculata (L.) Walp. 1843 (Fabaceae) à Yaoundé. Cameroun. Entomol. Faun., 66: 47-59. DOI:

10.1017/S172758414000307/qicipe201 4

Roubik DW. 1995. Pollination of cultivated plants in the tropics. FAO Agricultural Services Bulletin, United Nations.

Schippers RR. 1998. Solanum scabrum and related Black Nightshade species. Notes on Huckleberry, Natural Resources Institute, University of Greenwich, London, p. 17.

Schippers RR. 2000. African indigenous vegetables: An overview of the 
cultivated species. Notes on Huckleberry, Natural Resources Institute, University of Greenwich, London, p. 214.

Tchuenguem FFN, Messi J, Pauly A. 2001. Activité de Meliponula erythra sur les fleurs de Dacryodes edulis et son impact sur la fructification. Fruits, 56(3): 179188.

Tchuenguem FFN, Messi J, Brückner D, Bouba B, Mbofung G, Hentchoya HJ. 2004. Foraging and pollination behaviour of the Apis mellifera adansonii on Callistemon rigidus flowers at Ngaoundéré (Cameroon). $J$. Cam. Acad. Sci., 4: 133-140. DOI:10.4314/cajeb.v5i1.44442

Tchuenguem FFN. 2005. Activité de butinage et de pollinisation d'Apis mellifera adansonii Latreille (Hymenoptera: Apidae, Apinae) sur les fleurs de trois plantes à Ngaoundéré (Cameroun): Callistemon rigidus (Myrtaceae), Syzygium guineense var. macrocarpum (Myrtaceae) et Voacanga africana (Apocynaceae). Thèse de Doctorat d'Etat, Université de Yaoundé I, 103 p.

Tchuenguem FFN, Ngakou A, Kengni BS. 2009a. Pollination and yield responses of cowpea (Vigna unguiculata L. Walp.) to the foraging activity of Apis mellifera adansonii (Hymenoptera: Apidae) at Ngaoundéré (Cameroon). Afr. $J$. Biotech., 8: 1988-1996.
Tchuenguem FFN, Kingha TBM, Brückner D. 2014. Diversité des insectes floricoles et son impact sur les rendements fruitiers et grainiers de Arachis hypogaea L. (Fabaceae) à Dang (NgaoundéréCameroun). Int. J. Biol. Chem. Sci., 8(3): 983-997.

DOI: http://dx.doi.org/10.4314/ijbcs.v8i3.14

Teppner H. 2005. Pollinators of tomato, Solanum lycopersicum (Solanaceae), in Central Europe. Phyt. Ann. Rei. Bo., 44(2): 217-235.

Tchuenguem FFN, Nepidé NC. 2018. Efficacité pollinisatrice de Apis mellifera L. (Hymenoptera: Apidae) sur Sesamum indicum (Pedaliaceae) var. Graine Blanche et Lisse à Dang (Ngaoundéré, Cameroun). Int. J. Biol. Chem. Sci., 12(1): 446-461. DOI: 10.4314/ijbcs.v12i.1.35

Zra GV, Mazi S, Azo'o EM, Fameni TS, Tchuenguem FFN. 2020. Impact de l'activité de butinage de Dactylurina staudingeri Gribodo (Hymenoptera: Apidae) sur la pollinisation et les rendements de Cajanus cajan (L.) Millspaugh (Fabaceae) à Dang (Ngaoundéré, Cameroun). Cameroon J. Exp. Biol., 14(1): 1-9. DOI: 10.17509/cjeb.v4i2.24203 